\title{
Література:
}

1. Любківський О. Художні трактати про місто, що колись називалося Czernowitz. Чернівці : Друк ФОП Глібка О. В., 2017. 460 с.

2. Митці Буковини : Енцикл. довід. / Авт.-упоряд. Т. Дугаєва, І. Міщенко. Т. 1. Чернівці : Золоті литаври, 1998. $128 \mathrm{c.}$

3. Осачук С., Дугаєва Т. Чернівці. Czernowitz : Художній альбом / Kunstalbum. Чернівці : Видавництво «Книги - XXI», 2017. 362 с.

4. Севернюк Т. Летючий промінь вічності... художник Наталя Ярмольчук. Чернівці : Золоті литаври, 2007. 304 с.

5. Ярмольчук Н. Ностальгія : Набір листівок. Чернівці, 1996.

DOI https://doi.org/10.30525/978-9934-26-004-9-53

\section{ТВОРИ ДЕКОРАТИВНО-ПРИКЛАДНОГО МИСТЕЦТВА У РОБОТАХ АНАТОЛІЯ КАЛИТКА}

\author{
Молинь Н. I. \\ викладач кафедри образотворчого мистечтва \\ та академічних дисииплін \\ Косівського інституту прикладного та декоративного мистеитва \\ Львівської національної академії мистечтв \\ м. Косів, Івано-Франківська область, Украӥна
}

Народна творчість - це підгрунтя, на основі якого розвивається мистецтво, адже кожен твір народного мистецтва - це уособлення мудрості поколінь. Народна творчість лягла в основу багатьох творів образотворчого мистецтва, надихнула багатьох художників.

Вагомою постаттю в історії образотворчого мистецтва Гуцульщини виступає Заслужений художник України, доцент кафедри образотворчого мистецтва та академічних дисциплін Косівського інституту прикладного та декоративного мистецтва Львівської національної академії мистецтв - Анатолій Миколайович Калитко [1, с. 4]. Творча та педагогічна діяльність А. Калитка в нашому навчальному закладі досягла вже півстоліття. Цьому сприяло не тільки творче обдарування художника, а й висока працездатність, намагання глибоко й правдиво відтворювати навколишню дійсність.

Плідний доробок художника відображений у трьох жанрах: портрет, пейзаж та натюрморт. А. Калитко віддає перевагу реалістичному 
зображенню дійсності [4, с. 10]. Його манера письма експресивна, а колорит дзвінкий, насичений. Гуцульщина стала фундаментальною основою творчості художника. Художник спостерігає за карпатською природою, гірськими селами та змальовує побут гуцулів. А. Калитко активно звертається до використання народних традицій та творів декоративно-прикладного мистецтва у своїх полотнах.

Художник майстерно відображає предмети народного мистецтва, він цінує народну творчість, вміло розкриває самобутність та національний колорит.

У своїй статті «Етніка у творчості вчених художників « Петрова О. виділяє кілька способів опрацювання фольклорного мистецтва. Беручи до уваги твори А. Калитка можемо віднести його творчість до другого способу «співбесіди» 3 етномистецтвом. У його творах немає декоративної стилізації, народність просто перекликається 3 академічними традиціями [5, с. 56].

Збагачуючи мову своїх творів Художник наповнює їх предметами народних промислів. У портреті це народний стрій та аксесуари («Портрет лауреата Державної премії ім. Т. Шевченка Ганни Василащук» (1973), «Роман» (2001), «Нащадок опришків» (2005), «Володя» (2009), ) декоративні доріжки, ліжники («Гуцулка з села Річка» (2004)), дерев’яні тарелі на тлі («Портрет різьбяра Степана Бзунька» (2002)), чи предмети домашнього вжитку в руках («Портрет керамістки Ірини Серьогіної» (2009)). У пейзажі художник вводить людські постаті в національному вбранні («Розмова» (2006), «Біля церкви в Соколівці» (2010), «На Великдень» (2010), «Карпатська осінь» (2010), «Свято у Карпатах» (2016)). Натюрморти А. Калитка це переважно постановки 3 квітами та предметами домашнього вжитку. Через використання даних виробів митець наповнює твори ідейно-змістовим звучанням, допомагає конкретизувати сюжет та національну своєрідність.

Звертаючись до жанру натюрморту А. Калитко обирає олійну, гуашеву чи акварельну техніки. Його колористична манера протягом творчої діяльності витримана в гармонійній, насиченій, полігамній палітрі з тональними градаціями. Натюрморт, як і інші твори, художник виконує переважно в реалістичній манері.

А. Калитко, як правило, виставляє постановки на лаковій поверхні стола. Іноді вкриває його декоративними тканинами, вишитими рушниками чи скатертинами. Він зображує на своїх полотнах косівську кераміку: вази, глечики, тарелі, горнятка; плетені з лози кошики, дерев'яний посуд, боднарські вироби, гуцульські писанки, декоративні 
доріжки, рушники, килимки, а також щедро наповнює їх квітами, плодами, грибами.

Особливим захопленням митця $\epsilon$ написання квітів. Художник створив ряд натюрмортів з об'ємними букетами у косівських керамічних вазах, де ваза вміщена у центр композиції $є$ центральною віссю картини. Наприклад у творах «Півники» (1995), «Квіти арніки» (2003), «Чорнобривці» (2005), «Маки» (2005), «Осінній подих» (2009). Найчастіше А. Калитко змальовує польові квіти: ромашки, волошки, маки, дзвіночки («Квіти з полонини» (2006), «Полонинські квіти» (2008)) а також вирощені на власній клумбі: троянди, чорнобривці, півонії, гілочки калини, бузку, горобини ( «Бузок» (1996), «Бузок» (2004), «Чорнобривці» (2005)).

В творчому доробку художника зустрічаються різні за композиційною структурою роботи. А. Калитко не захоплюється деталями, проте його твори виразні та гармонійно цілісні. Натюрморт «Маківки 3 яблуками» (2005) побудований у замкнутому композиційному середовищі. Художник часто експериментує зображуючи предмети то в середовищі інтер'єру («Осінній натюрморт» (2005), «Маки 3 дзвіночками» (2011), «Маки» (2005), «Натюрморт 3 горобиною» (2009)), то навпроти вікна на контражур («Натюрморт біля вікна» (2005)), а іноді творчі пошуки виходять за межі інтер'єрного середовища як у творі «Квіти весни» (2008). Художник зобразив натюрморт на пленері узагальнивши навколишнє середовище та зосередив увагу на предметах. У всіх вищезгаданих натюрмортах квіти вміщені у керамічні вази.

Цікавими в доробку А. Калитка $є$ натюрморти із зображенням предметів домашнього вжитку («Натюрморт 3 грибами» (1989), «Натюрморт $з$ помідорами» (1996), «Осінній натюрморт» (1999), «Бузок 3 писанками» (2000), «Натюрморт з шипшиною» (2008)). Майже у всі із них художник вводить квіти. Так, наприклад, у творі «Натюрморт 3 грибами» (1989) бачимо відцентровану композицію, в якій ліва та права частини урівноважені між собою. Стіл накритий рушниками, а на ньому розміщений глечик з пишним букетом польових квітів та невелике розписане горнятко. Їм протиставлений кошик, який лежить на площині столу. Він урівноважує зсунутий ліворуч букет. На передньому плані розсипані гриби.

Отже, апелюючи до народної творчості митець милується декоративними предметами зберігаючи національну ідентичність. Традиції народного мистецтва продовжують жити та полотнах митця. 


\title{
Література:
}

1. Анатолій Калитко. Живопис. Альбом / Автор-упорядник Молинь В. Львів, 2020. 80 с., іл.

2. Димшиць Е. О. Твори декоративно-прикладного мистецтва в натюрмортах українських художників (кін. 1950-х - поч. 1970-х років). Народна творчість та етнографія. 1986. № 3, С. 59-61.

3. Зорко А. Є. Натюрморт у класичному живописі та академічній художній освіті. Вісник КНУКіМ. Серія : Мистецтвознавство. 2011. Вип. 25, С. 36-43.

4. Молинь В., П'ясецька В. Мелодія живопису Анатолія Калитка. Альбом. Івано-Франківськ: Місто НВ, 2012. 128 с., іл.

5. Петрова О. Етніка у творчості вчених художників. Актуальні проблеми мистецької практики і мистецтвознавчої науки. 2016-2017. Вип. 8-9, С. 50-58.

DOI https://doi.org/10.30525/978-9934-26-004-9-54

\section{ТВІР І. ДРЯПАЧЕНКА «КУТОЧОК САДКА РОСІЙСЬКОГО КОНСУЛА У ФЛОРЕНЦЇ̈»}

\author{
Мячкова Т. O. \\ аспірантка кафедри теорії та історії мистецтва \\ Національної академії образотворчого мистеитвва і архітектури \\ м. Київ, Украӥна
}

На сайті Російської антикварної галереї було розміщено зображення картини І. Дряпаченка «Куточок саду». В інформації до твору вказано: картон, олія, 42,7х70,5 см, перша третина XX ст. [2]. У творі відображено характерне для теплого клімату Італії прикрашення саду. Зокрема, по центру композиції, поміж грунтової доріжки та огорожі, стоять діжки із лимонними деревами та квіти у горщиках. Оригінальний ракурс, камерність мотиву, фрагментарність зображення створюють відчуття присутності у затишному куточку саду садиби. Можна припустити, що дана картина «Куточок саду» - це твір І. Дряпаченка 1912 р. «Куточок садка Російського консула у Флоренції».

Про перебування І. Дряпаченка у Флоренції наявна інформація в документах Центрального державного архіву-музею літератури i мистецтва України. Відомо, що 1912 р. Рада Вищого художнього 